\title{
Geopolítica como Ação Racional com Relação a Meios e Fins; Nacionalismo como Relação Afetiva
}

\author{
Rafael Mantovani ${ }^{1}$
}

Resumo: Este artigo pretende analisar geopolítica e fenômenos discursivos que funcionam como coesão nacionalista em dois conflitos do século XX: a Segunda Guerra Mundial e a Guerra Fria. Táticas de guerra e de legitimação são pensadas à luz de autores como Halford Mackinder, Zbigniew Brzezinski, Max Weber e Michel Foucault, para, ao fim, problematizar a idéia de Direito Internacional.

Palavras-Chave: Estratégia; Nacionalismo; Guerra; Justiça

Abstract: This essay intends to analyze geopolitics and discursive phenomena which operate as nationalist cohesion in two conflicts of the 20 $0^{\text {th }}$ century: The Second World War and the Cold War. Tactics of war and legitimation are thought in light of authors such as Halford Mackinder, Zbigniew Brzezinski, Max Weber and Michel Foucault in order to, thus, render problematic to the International Right.

Key Words: Strategy; Nationalism; War; Justice

\section{INTRODUÇÃO}

Em 1977, Michel Foucault começa a fazer estudos que lhe mostrariam a aparição da população como importante figura à qual os Estados precisaram se atentar em determinado momento da história. A partir dos fisiocratas, não é mais a soberania a grande questão da ciência política, mas sim, a gestão governamental e a disciplina, segundo ele. A questão da soberania não some, mas aparece como pano de fundo dessas duas outras preocupações do Estado. Talvez se poderia dizer que esta hipótese de Foucault se sustenta empiricamente cada vez mais, uma vez que os chefes de Estados considerados maus gestores, de acordos com os modelos ocidentais, são sistematicamente derrubados (mesmo que por interesses políticos e econômicos, trata-se de um "fazer justiça" apoiado por uma grande parte dos Estados), ainda que soberanamente enquadrados. No ano seguinte, ao dar o curso referente ao tema que estava estudando, Foucault se apresenta arrependido com relação ao nome do

\footnotetext{
${ }^{1}$ Rafael Mantovani é doutorando (2011) em Sociologia pela Universidade de São Paulo (USP). É mestre (2009) pela Pontifícia Universidade Católica de São Paulo (PUC/SP) em Ciências Sociais, com concentração na área de Antropologia, tendo sido convidado como pesquisador do Instituto Gino Germani do programa de pós-graduação da Universidad de Buenos Aires. É graduado (2005) em Ciências Sociais também pela PUC/SP. Tem experiência nas áreas de sociologia histórica comparada e antropologia cultural. Lattes: http://lattes.cnpq.br/7471017216843812. E-mail: $\underline{\text { mantovani@usp.br }}$
} 
curso que está ministrando (2008: 143): Segurança, território, população. Decerto, o motivo é que o território não é mais uma questão primordial para os Estados no mundo pósfisiocratas, mas sim a população.

Entretanto, em tempos de guerra, vêm à tona, com toda a força, ambas as idéias para legitimação dos conflitos. A (1) soberania em geral arranhada pela invasão de (2) territórios traz toda a carga emotiva para o desencadeamento dos embates. Logo, se no cotidiano dos Estados, o que justificaria a legitimidade do mando é a arquitetura que estabelece limites e liberdades para o desenvolvimento de uma população circulante, em tempos de guerra, estes homens cuidados pelo Estado são evocados pela máxima jurídica de obediência. Segundo Max Weber, este momento de obediência é o que pode conferir o máximo de sentido à vida e à morte do homem moderno.

Ao comparar esferas sociais com a esfera religiosa, Weber (2006) reconhece duas esferas estranhas à religião. A comunidade (parentela) e a economia. Em seguida, encontra três esferas concorrentes a ela: a política, a estética e a erótica. Finalmente, a esfera que nega a religiosidade: a intelectual. O sentimento religioso é uma busca por sentido da vida, cada vez com menos força devido, em grande medida, aos graus de racionalização e do imperativo de coerência que crescem com o tempo.

E por que a esfera política é concorrente em relação à esfera religiosa? Porque de uma forma muito mais bem acabada do que a religião, o Estado pode dar sentido à vida e à morte. Mesmo sendo uma associação jurídica impessoal a priori, a comunidade nacional é aquela que fornece a possibilidade de consagração da morte, afinal, se a vida e a morte não apresentam sentido, "distingue-se a morte em campanha pela facto de aí - e nessa tamanha quantidade somente aí - o indivíduo poder crer saber morrer 'por' alguma coisa" (Weber, 2006: 331). A consagração da morte é um monopólio da idéia de guerreiro, e em uma perspectiva bastante nietzschiana, a consciência de força e ameaça coloca o homem em uma "renovada violência" (Idem: 329). A guerra passa a ser um êxtase comunitário de potencial renovador, por mais que a base dos Estados seja societal. Para compreender as distinções entre comunidade e sociedade, é necessário fazer um pequeno apanhado sobre a teoria da ação.

Uma relação social é societal quando a ação racional é (1) orientada com relação a fins e meios ou quando é (2) com relação a valores. Em contrapartida, uma relação é comunitária quando é (1) emotiva ou (2) tradicional (Weber, 1964: 33). Uma sociedade é caracterizada 
pela impessoalidade, enquanto que a comunidade é caracterizada pelo seu oposto. Desta maneira, o mercado pode ser compreendido como a forma mais acabada de sociedade. No ato de compra e venda, não importa a pessoa do vendedor ou do comprador, mas o contrato impessoal de acordo com relação a valores e mercadorias. Entretanto, dentro de todas as esferas, há processos de "pessoalização" e "impessoalização", ou seja, "comunitarização" e "societarização". Logo, se por um lado, o mercado é impessoal, ele cria lados comunitários como, por exemplo, comunidade monetária, comunidades de crédito que se baseiam em parentesco etc. As características comunitárias e societárias se entrelaçam nas relações, embora se possa dizer que a lógica intrínseca do mercado seja um princípio societal; da mesma forma que a lógica intrínseca da família seja comunitária.

A esfera política não é diferente: apresenta a sua faceta societal (procedimentos impessoais, burocráticos, universalismo de procedimento), assim como a sua face comunitária que tem o seu acabamento mais perfeito no nacionalismo. O homem moderno domesticado não tem senão no nacionalismo a forma legalmente aceita de exercer a violência. 0 momento da guerra é exatamente aquele em que os aspectos societários e comunitários do agrupamento político são elevadamente ativados. De um lado, os dispositivos jurídicos para o recrutamento; de outro, a injeção simbólica para a glorificação do sacrifício em nome de uma causa. Do ponto de vista prático da guerra em andamento, por um lado o Estado precisa de estratégia, ou seja, a ação com relação a meios e fins; de outro, força comunitária que dê sustentação e apoio na guerra, ou seja, relação afetiva entre os concidadãos que se nutrem do pathos nacional de ataque e defesa em nome dos ideais comunitários.

Observando a Segunda Guerra Mundial e a Guerra Fria, podem-se averiguar estranhas condutas, muitas vezes contraditórias, dos chefes de Estado. Em face de determinadas estratégias, é necessário sacrificar uma lógica identitária, assim como em nome de outras estratégias, uma constelação identitária ou uma lógica amigo-inimigo precisa ser criada ou evocada.

Contudo, a relação não é unilateralmente do nacionalismo que serve como combustível para a guerra; a possibilidade da guerra, em tempos de paz, também é fomentador do nacionalismo. Já no início do século, a autora marxista Rosa Luxemburgo aponta o importante papel do militarismo para o nacionalismo e para o desenvolvimento econômico:

"Para ela [a classe burguesa], sob três aspectos tornou-se hoje o militarismo indispensável; primeiro, como meio de luta na defesa de interesses 'nacionais' concorrentes contra outros grupos 'nacionais'; segundo, como a forma de emprêgo mais 
importante, tanto do capital financeiro como do capital industrial, e terceiro, como instrumento da dominação de classe sobre os trabalhadores, no interior" (Luxemburg, 1975: 32-3).

Quando se despediu da presidência dos Estados Unidos, Dwight Eisenhower (1890-1969) alertou para o crescimento descontrolado da permanente indústria de armamentos estadunidense (Jarecki, 2005) que, sendo indústria, gera empregos e rendimentos; contudo, produz também simbologia.

Para se pensar nas estratégias (relação com relação a fins e meios) da Segunda Grande Guerra e da Guerra Fria, é necessário entender a corrente de pensamento inaugural da geopolítica: Halford Mackinder (1861-1947), geógrafo responsável pela inserção da Geografia em Oxford como disciplina. Este autor trouxe implicações teóricas que foram importantes para os conselheiros de Estado aqui brevemente analisados: Karl Ernst Haushofer (1869-1946), geopolítico a serviço da Alemanha nazista, Nicholas Spykman (18931943) nascido na Holanda e geoestrategista dos Estados Unidos, e Zbigniew Brzezinski (1928), polonês erradicado nos Estados Unidos.

Por outro lado, para se entender a lógica de guerra que busca a carga emotiva (relação afetiva), Foucault pode nos oferecer uma reflexão interessante: a existência de uma estrutura binária, a necessidade de estar forçosamente contra alguém, ou seja, de um lado ou de outro (Foucault, 1999: 59-60). Mais do que isso, tal discurso de defesa que não se pretende neutro é abertamente um discurso de perspectiva, mas que fala do direito à luta contra o inimigo. Modo binário de pensar que, segundo Foucault, provém do discurso da luta de raças formulado no século XVII e que chega à idéia de luta de classes no século XIX (Idem: 70-72). Esses discursos de combate geram o sentimento de necessidade de purificação permanente, e passa-se assim da idéia de "defender-se da sociedade" para a máxima: "Temos de defender a sociedade". As ficções de defesa são inúmeras (e, como mencionado, pensaremos em dois conflitos: a Segunda Guerra e a Guerra Fria), mas a norma jurídica é fixa. Da mesma forma, se poderia afirmar que a soberania se legitima com um raciocínio circular:

"O bem público é essencialmente a obediência à lei, à lei do soberano sobre esta terra ou à lei do soberano absoluto, Deus. Mas, como quer que seja, o que caracteriza a finalidade da soberania, esse bem geral, não é afinal de contas outra coisa senão a submissão a essa lei" (Foucault, 2008: 131). 
A soberania como a possibilidade de fazer a guerra foi melhor definida, curiosamente, por um alemão: Carl Schmitt (1888-1985). Teórico de prestígio do início XX, que, apesar de não escrever para o nazismo, se tornou eminência parda para o regime. Porém, aquilo que Schmitt escreveu parece não só cabível para o III Reich como irá se tentar demonstrar.

O inimigo torna-se peça fundamental na argumentação sobre o papel do político e do Estado. A essência da política é a possibilidade de determinar o inimigo a ser combativo e destruí-lo fisicamente. O autor faz questão de afastar as falácias liberais sobre os choques entre homens: a guerra a que ele se refere não se trata de discussão no campo espiritual, nem de concorrência no campo econômico: a guerra é a possibilidade de ataque militar com a finalidade de liquidação física do inimigo. Soberano é aquele que determina o caso de exceção; política é a possibilidade de mover em direção à guerra. O que há de peculiar no pensar político é o fato de ter como pressuposto ou possibilidade o confronto.

"O conceito de Estado pressupõe o conceito de político" abre o texto $O$ conceito do político publicado em 1932. Portanto, se o critério simples do político é a determinação do inimigo a ser combatido e o corpo jurídico-político dele deriva, "ao Estado como uma unidade essencialmente política pertence o jus belli, isto é, a possibilidade real de, num dado caso, determinar, em virtude de sua própria decisão, o inimigo, e combatê-lo" (Schmitt, 1992: 71). A democracia schmittiana é aquela que não atenta para as diferenças. Aliás, o intuito de outros escritos do autor é o de frisar a impossibilidade de conciliação entre democracia e liberalismo: a primeira é a expressão da maioria do povo; o segundo, a defesa das minorias. Tendo isso em mente, não assusta o papel do Estado segundo o autor e a conclusão a que chega sobre a que ponto pode chegar a determinação do inimigo pelo Estado nas passagens seguintes:

"A função bem desempenhada de um Estado normal consiste porém sobretudo em produzir no interior do Estado e de seu território uma satisfação completa, estabelecer 'tranqüilidade, segurança e ordem'... Essa necessidade de satisfação dentro do Estado leva, em situações críticas, a que o Estado enquanto unidade política, enquanto se mantém, determine por si mesmo também o 'inimigo interno'” (Idem: 72).

Pode parecer que esta é uma teoria do próprio nazismo. Porém não foi: Schmitt não foi favorável à posse de Adolf Hitler e muito menos era um anti-semita. Segundo Hans Flickinger, na apresentação do livro em questão, reflete-se acerca do gosto que Schmitt adquiriu pelo poder. Mas durante o nazismo, "o preço, porém, pago por esta participação no 
poder foi a necessária adesão ao anti-semitismo e outras exigências ideológicas do regime nazista" (Flickinger Apud Idem: 15-6).

De fato, a eleição de qualquer grupo como inimigo não desmerece o caráter político da ação. Mas a eleição em si do inimigo e o combate a ele é o que define um político e um Estado como tais. Tal fato não contradiz a sua frase do texto de 32:

"O inimigo político não precisa ser moralmente mau, não precisa ser esteticamente feio; não tem que surgir como concorrente econômico, podendo talvez até mostrar-se proveitoso fazer negócios com ele. Pois ele é justamente o outro, o estrangeiro, bastando à sua essência que, num sentido particularmente intensivo, ele seja existencialmente algo outro e estrangeiro, de modo que, no caso extremo, há possibilidade de conflitos com ele..." (Idem, 1992: 52).

Não há nada além de ser ontologicamente o outro necessário para que um grupo seja eleito como inimigo. Fazer política é fazer inimigos e fazer a guerra. Não importa se o inimigo é "bom" ou é "mau".

\section{Mackinder e a Segunda Guerra Mundial}

Segundo Mackinder, sempre existiu um confronto entre dois tipos de força: o terrestre e o marítimo $^{2}$. A aviação ainda não era, à época, utilizada como ferramenta de guerra. Porém, mesmo depois, Mackinder não reconheceu a força e a independência que o combate aéreo mereceu posteriormente: ao contrário, defendia a força aérea como arma tática auxiliar. Portanto, Mackinder estabeleceu a dicotomia continentalismo versus oceanismo. Duas categorias essenciais surgem na sua construção teórica:

- O Midland Ocean, que é a conjugação de todos os oceanos pelo mundo. Ao contrário das versões mais recorrentes na cartografia, o autor pensa os mares como uma única área de ação totalmente interligada;

- Aquilo que, de início, chamou de Pivot Area e depois rebatizou de Heartland.

A Pivot Area ou o Heartland é a região que corresponde mais ou menos ao gigantesco território russo, o que seria o núcleo do continente eurasiático. Esta região pode possibilitar uma economia autárquica e um invencível poder terrestre. As características que dão a primazia desta região sobre outras são três: a extensão (1) e a topografia plana (2) dessa região e o isolamento (3) do mundo exterior. Tais fatores, se essa região se tornasse anfíbia,

\footnotetext{
${ }^{2}$ Quando não mencionada a fonte, dados obtidos de Mello, 1999.
} 
ou seja, não se restringisse ao aperfeiçoamento do combate terrestre, a possibilitariam tornar-se a de maior poder do mundo.

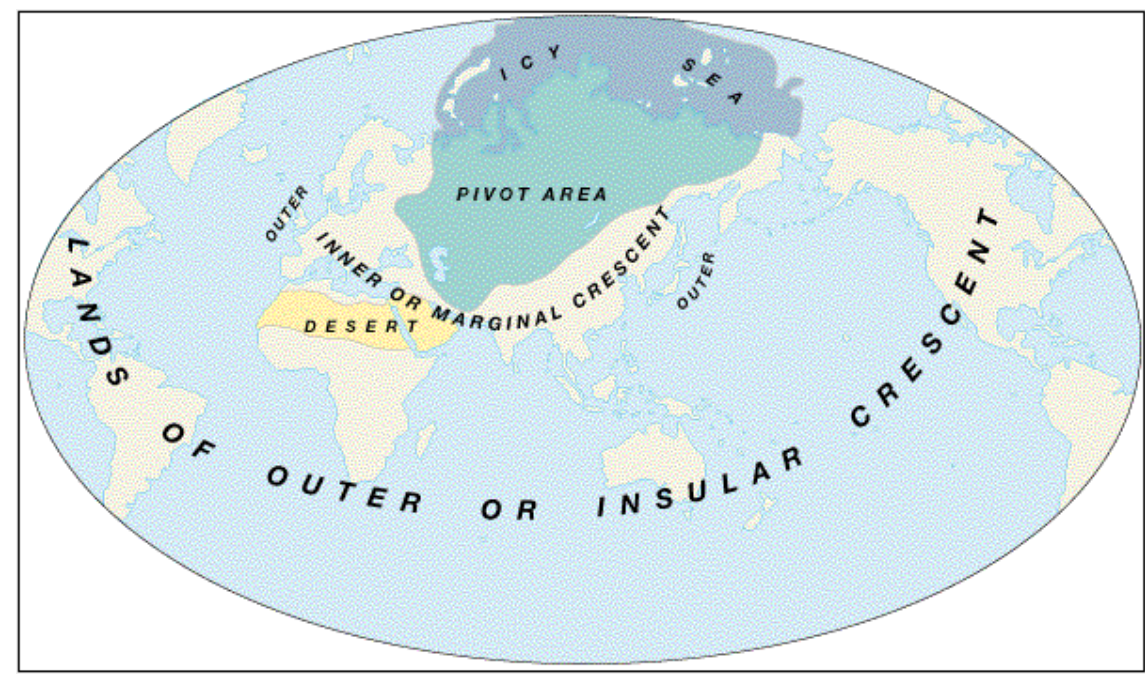

Abaixo do Heartland, estava o Inner Crescent, "o espaço natural de expansão do poder terrestre que, de posse do núcleo basilar eurasiano, procurava conquistar as regiões periféricas e obter saída para o oceano" e "era também a barreira física de contenção ou a primeira linha de defesa do poder marítimo" (Mello, 1999: 47).

Exterior ao Inner Crescent estava o Outer Crescent, regiões em que as potências marítimas não sofriam com o poder continental.

Sendo assim, Mackinder acaba por estabelecer uma nova forma de olhar a geografia mundial: antes, a predileção estava assente sobre a Europa; agora, a preocupação se dirige a oeste. Ao mesmo tempo, pode-se dizer que o autor fala sob a ótica do determinismo geográfico ou do materialismo geográfico, já que via nas inovações tecnológicas, como locomotivas e ferrovias, a possibilidade de superação do poder terrestre em relação ao poder marítimo.

E por que tão grande interesse na Eurásia?

\footnotetext{
"Segundo indicadores de 1985, o mundo possuía a população de 4,7 bilhões de pessoas, um produto bruto de 12,3 trilhões de dólares e uma área terrestre de 134 milhões de $\mathrm{km}^{2}$. A Eurásia tinha uma população de 3,3 bilhões de habitantes, um produto bruto de 7,4 trilhões de dólares e uma área de 51 milhões de $\mathrm{km}^{2} \ldots$ Isso equivale dizer que, grosso modo, a Eurásia controlava $70 \%$ da população, $60 \%$ do produto bruto e $40 \%$ da área do globo" (Idem: 154-5).
}

Controlar essa região significaria controlar todo o cenário geopolítico e econômico global. Por isso, Mackinder alertava a elite inglesa do perigo de uma aliança entre Alemanha e 
Rússia, fator que insularia a Inglaterra na Europa e Ásia. Depois da I Guerra Mundial, o geógrafo sugere à diplomacia britânica um cordon sanitaire (cordão sanitário) que dividiria a Alemanha e a Rússia. A área que vai do mar Negro ao Adriático, que é composto por Polônia, Tchecoslováquia, Hungria, lugoslávia, Bulgária, Romênia e Grécia, ficaria sob a tutela inglesa para assegurar que um poder incomensurável se criasse pela junção dos dois temidos países. Assim, a Inglaterra poderia prosseguir com a sua hegemonia.

Faz-se notável um aspecto deixado a segundo plano que antecedeu a Segunda Guerra: o pacto de não-agressão assinado entre Hitler e Stálin em 23 de agosto de $1938^{3}$. Karl Haushofer não desconhecia a necessária neutralidade da URSS a princípio e a necessidade de dominação deste território para sucesso na guerra. Em 10 de setembro de 1939, os nazistas invadem a Polônia, sob o pretexto do atentado a uma estação de rádio alemã próxima da fronteira, forjado pelos próprios nazistas. Ao contrário do que houve com a Áustria e a Tchecoslováquia, na Polônia há a reação o que impede os países aliados a esse país permanecerem coniventes com a situação. Inicia-se a Segunda Guerra Mundial com a declaração de guerra da Inglaterra e da França à Alemanha.

Churchill dizia em 1936 que a Inglaterra deveria permanecer neutra de uma guerra européia, mas os acordos de Monique foram desrespeitados com a invasão alemã à Polônia. De outra perspectiva, o cordão sanitário, estabelecido para impedir a dominação da Pivot Area pelo inimigo, estava sofrendo ataques: a Inglaterra necessitaria estrategicamente reagir.

Contudo, Hitler parece não ter conseguido se deixar levar pelas preocupações geoestratégicas e o seu espírito fracófobo falou mais alto: após começar as invasões no cordão sanitário, se dirige a oeste para dominar a França, que assina o armistício em 22 de junho de 1940. Em setembro do mesmo ano, é criado o Eixo Roma - Berlim - Tóquio. Em novembro de 1940, os nazistas convidam os russos a fazer parte do Eixo. A URSS não apresenta interesse em entrar na guerra, mas o convite faz-se emblemático: do plano de vista geoestratégico, tratar-se-ia de sucesso quase assegurado na guerra; entretanto, no plano dos discursos, toda uma reconstrução teria de ser realizada, afinal, se uma paz entre comunistas e nazistas foi dificilmente compreendida, uma aliança seria ideologicamente inconcebível. Mesmo assim, Vyacheslav Molotov (1890-1986), Comissário do Povo para Negócios Estrangeiros da União Soviética dizia:

\footnotetext{
${ }^{3}$ Dados históricos sobre a Segunda Guerra obtidos de Aquino, 1999.
} 
"Se se fala hoje das grandes potências européias, a Alemanha se vê na situação de um Estado que aspira a ver a cessação rápida da guerra e que deseja a paz, enquanto a Inglaterra e a França, que ainda ontem se proclamavam contra a agressão, são pela continuação da guerra e contra a paz. Como vêem, os papéis mudam."

Contudo, a aliança era improvável. Provavelmente já com isso em mente, desde junho Hitler já vinha planejando a Operação Barbarossa, uma invasão, segundo ele, rápida no território soviético. A invasão veio a acontecer em junho de 1941, depois de ter dominado quase toda a Europa continental e tentado a dominação da Inglaterra em agosto. Logo, uma parte do arsenal de guerra indispensável no ataque à Rússia foi utilizada na campanha a oeste, além da necessidade de ajuda constante ao exército italiano.

Em 22 de junho de 1941, a Alemanha começa a invasão à URSS, desrespeitando o acordo de não-agressão com este país. O avanço se dá em três frentes: em direção a Leningrado e aos países bálticos, pelo centro em direção a Moscou, e pelo sul em direção à Ucrânia. Curiosamente, se o inverso russo mais forte do século XIX foi exatamente o daquele ano em que Napoleão tentou a conquista, o inverso mais penoso do século XX foi exatamente o de 1941 com 30 negativos. Junto com o inverno, os alemães têm superar a resistência russa, o que leva a uma perda de 20 mil soldados alemães por semana.

Em julho de 1943, a batalha de Kursk inverte as ofensivas da guerra. Em novembro, começa a contra-ofensiva soviética arrebatadora sobre os alemães. Hitler proíbe o general Friedrich Paulus de se render. A vitória foi vista como triunfo do sistema comunista e exacerba o prestígio popular e o exército vermelho caminha em direção a Berlim e, por onde passa, engloba sua área de influência através da presença das forças armadas. Anexa a Estônia, a Letônia, a Lituânia, a Polônia, a Tchecoslováquia, a Hungria e Bulgária.

No dia 6 de julho de 1944, as tropas aliadas chegam a Normandia, comandadas pelo general estadunidense Dwight Eisenhower. Dia 25 de julho, Mussolini é preso. Dia 3 de setembro, a Itália assina um armistício secreto. O Eixo é sufocado a oeste pelos soviéticos e a leste pelas forças européias e norte-americanas. Os aliados chegam a Berlim em março, com um despejo de toneladas de bombas sobre a população civil. Em 28 de abril de 1945, Mussolini é assassinado e, em 30 do mesmo mês, Hitler se suicida. Em 7 de maio, o almirante Karl Dönitz, sucessor de Hitler, assinou a capitulação alemã.

Ao final da Segunda Guerra, há a inauguração histórica de um tipo de desfecho de guerra que irá se seguir para todas as subseqüentes: um tribunal. Desde 1864, com a Paz de 
Westphalia, havia se estabelecido a Razão de Estado, ou seja, a obediência ao corpo jurídicopolítico a que determinado indivíduo pertença. Em caso de embate entre Estados, o que haveria ao final seriam vencedores e perdedores. Ao final da Segunda Guerra, ao título de perdedor se soma o de criminoso. No que diz respeito a esta mudança de paradigma, se prevê uma necessidade de predisposição do sujeito para se colocar contra o Estado ao qual se está legalmente subordinado. Afinal, é esta a grande questão posta por Arendt, ao chamar de banalidade do mal justificar, perante um juiz, uma atrocidade cometida com base na obediência:

"A defesa aparentemente teria preferido que ele se declarasse inocente com base no fato de que, para o sistema legal nazista então existente, não fizera nada errado; de que aquelas acusações não constituíam crimes, mas 'atos de Estado', sobre os quais nenhum outro Estado tinha jurisdição (par in parem imperium nom habet), de que era seu dever obedecer e de que, nas palavras de Servatius, cometera atos pelos quais 'somos condecorados se vencemos e condenados à prisão se perdemos'" (Arendt, 1999: 32-33).

A defesa à idéia de Tribunal Internacional feita por Arendt parte do pressuposto de que a obediência a um Estado exerce uma incapacidade de refletir criticamente sobre os próprios atos, por mais atrozes que sejam. O problema desta visão é tentar imprimir ética à visão do vencedor: os aliados que atacaram Dresden (que não era um alvo militar, mas uma simples cidade alemã) nem tampouco aqueles que atiraram as bombas atômicas sobre Hiroxima e Nagasaki nunca foram postos como réus em um Tribunal Penal Internacional, por mais que tais ataques nunca tenham sido justificados.

A guerra continuará tendo os mesmos aspectos geopolíticos e de coesão comunitária, mas a partir do Tribunal de Nuremberg, para os concidadãos dos Estados Unidos, a catarse coletiva se vinculará também à necessidade predestinada de levar a justiça. E a vitória é imprescindível para carregar a justiça, uma vez que para os que vencem, a justificativa de obediência é válida; para os vencidos, não.

\section{Spykman, Brzezinski e a Guerra Fria}

O século XX, nos Estados Unidos, assistiu, entre outros, dois debates muito importante: o (1) do idealismo versus realismo político e (2) o do isolacionismo versus intervencionismo. Os idealistas se filiavam ao isolacionismo, enquanto os realistas, ao intervencionismo. 
O argumento realista e intervencionista tinha sua base em uma novidade trazida à tona por Mackinder:

"De agora em diante, na era pós-colombiana, novamente nos defrontamos com um sistema político fechado e, o que não tem menos importância, a sua esfera de ação será o mundo inteiro. Todas as explosões de forças sociais que se produzam, em vez de se dissiparem nem circuito circunvizinho de espaço desconhecido no qual dominam a barbárie e o caos, serão fielmente refletidas desde os mais distantes rincões do globo e, devido a isso, os elementos débeis do organismo político e econômico do mundo serão destruídos" (Mackinder Apud Mello, 1999: 30).

Nicholas Spykman era o homem do intervencionismo. Professor da Universidade de Yale, defendia abertamente suas posições diante dos quadros que surgiam. Partia de um ponto de vista hobbesiano, em que os Estados nacionais estavam, entre si, num estado de guerra de todos contra todos em que aquele que não se protegesse da melhor forma sucumbiria.

Os isolacionistas argumentavam que a potência marítima que são os Estados Unidos estaria protegida pelos oceanos que a cercam. Spykman e outros intervencionistas redargüiam que as bases de defesa do território norte-americano deveriam estar no próprio continente eurasiático. Assim, a linha de defesa no próprio território seria a segunda linha de defesa. Para Spykman, imaginar que o território estadunidense fosse uma fortaleza era uma mera fantasia frente aos avanços tecnológicos e os riscos belicosos que o mundo corria. Numa relação globalmente conectada, não é possível que uma potência não tenha firmes bases militares, políticas e econômicas por onde quer que seja.

Em 1944, é publicado postumamente o livro The geography of the peace de Spykman. Nele, é tentado explicar aos Estados Unidos como criar a sua paz na Eurásia. Nesse amplo debate com Mackinder, faz-se uma inversão de suma importância: o Inner Crescent passa a se chamar Rimland.

“O novo vocábulo procurava ressaltar a geografia anfíbia daquelas regiões, ou seja, o fato de possuírem uma frente continental e outra oceânica. Contígua ao Rimland eurasiano estava a linha circunferencial marítima formada pelo Atlântico, Mediterrâneo, Índico e Pacífico, que contornava a Eurásia e tinha como pontos extremos as ilhas costeiras da Grã-Bretanha e do Japão. [...] O conceito estratégico de Rimland assume, no pensamento de Spykman, uma centralidade equivalente à do Heartland na concepção geopolítica de Mackinder. Assim como Heartland é a noção axial da teoria do poder terrestre, Rimland é a idéia nuclear em torno da qual convergem e se articulam todos os demais componentes geopolíticos estratégicos da teoria de Spykman" (Melo, 1999: 122).

O Rimland constituía toda a Eurásia continental que não fazia parte do Heartland. 


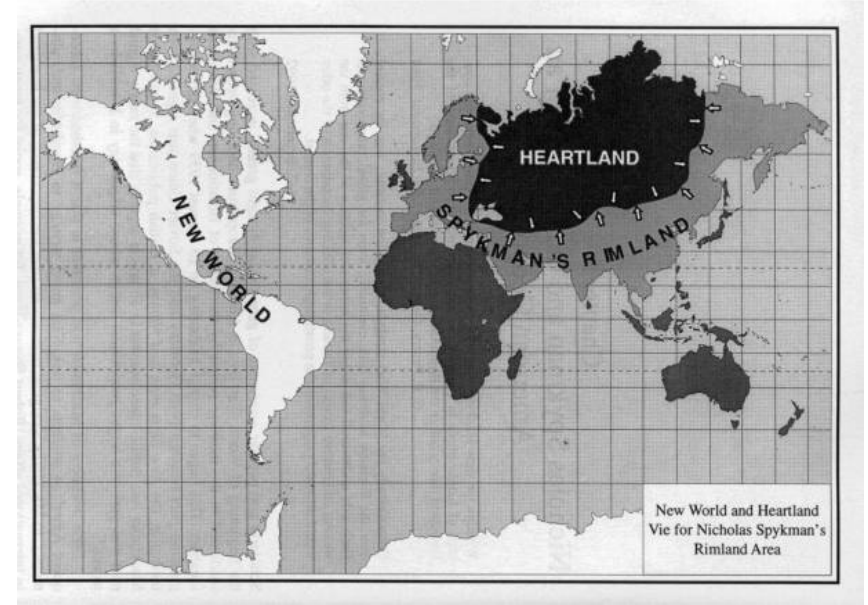

O pensamento de Mackinder era o de que aquele que se apossasse do Heartland se apossaria da Eurásia e teria grandes possibilidades de domínio global. Para Spykman, o raciocínio era outro: tudo começava no Rimland e terminava no controle mundial.

Com a expansão soviética ao final da segunda grande guerra, o bloco comunista está em posse de todo o Heartland e ameaçava incorporar o também o Rimland.

Em julho de 1945, o serviço secreto estadunidense intercepta uma mensagem do governo japonês ao seu embaixador em Moscou: o Estado japonês pede a intermediação dos soviéticos no acordo de paz com os EUA. Mesmo sabendo da futura rendição japonesa, os Estados Unidos lançam em 6 de agosto de 1945, a primeira bomba atômica sobre Hiroxima e, em 9 de agosto, outra bomba sobre Nagasaki. Percebia-se o crescimento da URSS como uma nação imperialista com grande probabilidade de rivalizar com os EUA. Era necessário mostrar aos soviéticos o poder bélico norte-americano, porém, eles eram aliados na Segunda Guerra, portanto, não poderiam ser um alvo. O alvo teria de ser outro, de preferência, bem próximo.

Em 1947, a Grã-Bretanha pede auxílio aos Estados Unidos, pois não está sustentando o apoio à Grécia (que está sob perigo devido à ameaça de guerrilheiros comunistas de tomar o poder) e à Turquia (cujo território a URSS reivindica parte). Para convencer o envio de soldados ao Mediterrâneo, Harry Truman (1884-1972) discursa:

"Os povos livres do mundo olham para nós esperando apoio na manutenção de sua liberdade. Se fracassarmos na nossa missão de liderança, talvez ponhamos em perigo a paz e o mundo, e certamente poremos em perigo a segurança da nossa própria nação."

Neste mesmo ano, inicia-se o rearmamento e a Guerra Fria. 
Por toda a Europa, os países se encontram em situação econômica muito problemática. A indústria alemã foi destruída na segunda guerra e não contava com $2 / 3$ do que fora havia 10 anos, a metade da indústria inglesa estava parada e a França e Itália se encontravam em situações parecidas. Os Estados Unidos criam o plano Marshall: um programa de apoio econômico para a recuperação econômica desses países, através de empréstimos. Em resposta, a União Soviética cria o Kominform, um comitê para o controle político dos países do leste europeu, estabelecendo a "sovietização" do socialismo; e o Comecon, este, para fins econômicos de reconstrução dos países anexados através de uma economia planificada.

Do ponto de vista militar, em 1959 é criada a OTAN, aliança entre EUA, Canadá, países capitalistas europeus e, em 1954, Alemanha Ocidental. Em resposta, a aliança militar do bloco soviético surge em 1955: o Pacto de Varsóvia.

Quando a China se torna comunista em 1949, os EUA vêem mais um país que concentra partes do Heartland e do Rimland se colocando mais a fim do bloco soviético e se sentem obrigados a reforçarem suas bases militares no Japão, em Taiwan, nas Filipinas e na Correia do Sul.

Uma tese não muito estapafúrdia pode ser a de que, devido à proximidade do bloco socialista ao Rimland, os EUA estrategicamente preconizaram todos os acordos e ações políticas, militares e econômicas das regiões fronteiriças com o bloco socialista. A aproximação dos EUA aos países europeus e asiáticos seria uma tentativa de incorporar uma parte do Rimland à sua área de influência.

Ao contrário da visão de Mackinder, para Spykman, o isolamento dos países que ocupavam o Heartland era um problema para estes: ao invés de proteger o território continental dos ataques, dificultaria a transformação dessas potências terrestres em potências anfíbias.

A partir das reflexões de Spykman, ao final da Guerra Fria, um terceiro geógrafo assume uma importância muito relevante apesar de trazer poucos dados novos: Zbigniew Brzezinski foi um dos assessores de Segurança Nacional do governo democrata de Jimmy Carter e deu as bases de ação para o governo Reagan.

No decorrer da Guerra Fria, os países sob a hegemonia norte-americana estão submetidos militar, política, econômica e militarmente. Os países do bloco soviético, ao contrário, apresentam uma submissão unicamente militar. Portanto, o bloco capitalista poderia sair vitorioso sem o confronto, aguardando o esfacelamento das relações sociais dos países 
envolvidos com o bloco socialista. Os soviéticos, em contrapartida, precisariam do confronto para se apoderar dos recursos do Japão e da Europa Ocidental.

O equilíbrio do terror impediria esse confronto. O forte armamento nuclear de ambos os lados impossibilitou que o confronto fosse deflagrado. Desta forma, o Estado norteamericano deveria conter o expansionismo soviético, equipando militar e economicamente as suas fronteiras, ou seja, o Rimland.

Talvez, Gorbatchev tenha percebido que Brzezinski estava correto e que a guerra estava perdida. A superioridade tecno-econômica do bloco capitalista era evidente e o equilíbrio apenas flagelaria o povo soviético. Os capitalistas ganham Guerra Fria e, pela terceira vez no século, há um exemplo que tenta mostrar que Mackinder estava equivocado ao imaginar a superioridade das potências continentais em relação às potências marítimas: na primeira guerra, a Inglaterra vence a Alemanha; na segunda, a Alemanha perde novamente pela ação de duas potências marítimas (EUA e Inglaterra) e uma terrestre (Rússia); e na Guerra Fria, novamente os EUA vencem uma potência continental: a URSS.

\section{CONSIDERAÇÕES FINAIS}

Ao fim da Guerra Fria, os Estados Unidos reconhecem novos inimigos: o terrorista, o narcotraficante e o islâmico fundamentalista. A identidade muçulmana foi uma chave fundamental para a defesa dos povos da Europa Oriental contra a anexação soviética sob a justificativa do paneslavismo. Com a anexação dos países bálticos, a URSS encontraria saída para o mar; logo, o islamismo foi realçado pelo bloco capitalista em contrapartida à identidade eslava. Anos depois, a identidade muçulmana passa a ser olhada com desconfiança. Não é um exemplo isolado. Quando a URSS anexou o Afeganistão, os Estados Unidos, no governo de Jimmy Carter e assessoria de Brzezinski, treinariam armariam os grupos islâmicos afegãos em 1979 para tomar o poder; grupo que se tornaria inimigo direto a partir de 2001.

Os Estados Unidos parecem ser o melhor exemplo para se compreender a idéia de violência renovada trazida pela guerra: não apenas a guerra em si, mas o seu ethos nacional sempre lembrado pelas produções cinematográficas que se tratam, em grande medida, de enormes catarses coletivas e comunitárias. A lógica binária está presente na Sociedade Ocidental como um traço da sua identidade e a guerra moderna aparece como o perigoso meio de dar 
sentido à vida e à morte. Assim sendo, torna-se compreensível como, mesmo que coerentemente em termos estratégicos, a aliança entre Alemanha nazista e a Rússia comunista não poderia de forma alguma ser assinada. Da mesma maneira, não é em defesa ao Rimland que os Estados Unidos se lançaram na Guerra da Coréia, do Vietnã, dos países bálticos e outros que faziam fronteira com a cortina de ferro: o combate, discursivamente, era em nome da liberdade.

Mais forte do que a necessidade de levar liberdade e democracia a todos, após a Segunda Guerra Mundial, os Estados Unidos têm a oportunidade de estabelecer seus tribunais como verdadeira responsabilidade de guerra: os Direitos Humanos são a perigosa ferramenta jurídica que procura ocupar o espaço que historicamente pertenceu à ética da fraternidade, sistematizada pelo sentimento religioso. Assim sendo, essa preocupante associação entre política e ética (duas esferas sem qualquer afinidade, uma vez que a política transforma homens em instrumentos) transforma a guerra moderna em uma enorme fonte de sentido, uma máquina de destruição que nenhuma refugiada do nazismo poderia pensar que se transformaria em uma gigantesca barreira ao pensamento crítico com relação à própria ação do sujeito.

\section{REFERÊNCIAS BIBLIOGRÁFICAS}

AQUINO, Maria Aparecida de. (1994) Anos de Chumbo (1939-1945). São Paulo, TV Cultura (documentário).

ARENDT, Hannah. (1999) Eichmann em Jerusalém. São Paulo, Companhia das Letras.

FOUCAULT, Michel. (1999). Em defesa da sociedade: curso dado no Collège de France (19751976). São Paulo: Martins Fontes.

(2008) Segurança, território, população: curso dado no Collège de France (1977-1978). São Paulo, Martins Fontes.

GIL, José. "Nação". (1989) In: Estado - Guerra. Enciclopédia Einaudi, vol. 14. Lisboa, Casa da Moeda. 
JARECKI, Eugene. (2005) Why we fight. BBC4 (documentário).

LUXEMBURG, Rosa. (1975) Reforma, revisionismo e oportunismo. Rio de Janeiro, Civilização Brasileira.

MELLO, Leonel Itaussu Almeida. (1999) Quem tem medo da geopolítica? São Paulo, Hucitec.

NIETZSCHE, Friedrich. (1998) Genealogia da moral: uma polêmica. São Paulo, Companhia das Letras.

SCHMITT, Carl. (1992) O conceito de político. Petrópolis, Vozes.

WEBER, Max. (1964) Economía y sociedad. Esbozo de sociología comprensiva. México, Fondo de Cultura Económica.

. (2006) Sociologia das religiões e consideração intermediária. Lisboa, Relógio

D’Água. 